\title{
The Making of a Cold War Turning Point: The Sino-Soviet Split and the Prelude to Detente with the United States, 1965-1968
}

\author{
Jein Do
}

\begin{abstract}
The Sino-Soviet border clash and the Nixon Doctrine make the year 1969 a watershed period in Sino-American and Soviet American rapprochement. However, there were subtle yet unmistakable shifts in the Chinese and Soviet positions towards the United States before the militarization of their conflict in 1969 set the Nixon Doctrine in motion. During the final collapse of the SinoSoviet alliance from 1965-1968, China and the Soviet Union began to redefine the nature and immediacy of the American threat as being limited. From 1965 , the Chinese leadership started alluding to the eventuality of rapprochement with the United States and downplaying the possibility of a direct Sino-American military confrontation over Vietnam. The Soviet Union, starting from late 1966, returned to the search for detente with the United States despite the war and became increasingly anxious to prevent a Sino-American rapprochement. The parallel devaluation of ideology as a consequence of the Sino-Soviet split from 1965-1968 predisposed them to mutual toleration and understanding with Washington after 1969.
\end{abstract}

Key Words: Sino-Soviet split, Vietnam War, Cultural Revolution, Mao Zedong, Lenoid Brezhnev, Richard Nixon, Lyndon Johnson, detente

$\mathrm{T}$ he Sino-Soviet border clash of March 1969 signaled the militarization of the long standing conflict between two former ideological allies. This was an ultimate manifestation of the unremitting hostility that had characterized their relationship since the early 1960s. However, since the durability of their conflict had already been confirmed previously and the drift toward open military conflict had been all but predictable, the larger historical significance of this incident does not lie in the final collapse of the Sino-Soviet alliance in itself. Rather, the truly remarkable consequence of the border war was the subsequent turnabout in their policies toward the United States, leading them to seek an alignment with their foremost ideological adversary.

In this connection, the majority of previous studies on Sino-Soviet relations,

*Jein Do (jeindo@gmail.com) is currently a lecturer in the Department of Global Korean Studies at Sogang University. She earned her MA in East Asian Studies from Harvard University and PhD in North Korean Studies from the University of North Korean Studies, Seoul, Korea. Her research focuses on North Korean political and diplomatic history.

The Korean Journal of International Studies Vol.12-1 (June 2014), 113-136.

http://dx.doi.org/10.14731/kjis.2014.06.12.1.113

(c) 2014 The Korean Association of International Studies 
particularly in addressing the parallel development of Sino-American and SovietAmerican détente in 1972, have rightfully focused on the post-1969 dynamics of the triangular relationship (Bundy 1998; Burr 2001; Cohen 2010; Chen 2001; Chen and Wilson 1998; Gaiduk 1996; Garver 1993; Harding 1992; Haslam 2011; Humes and Ryals 2009; Kirby, Ross, and Li 2005; Kissinger 1979; Macmillan 2007; Robinson and Shambaugh 1996; Shen and Danhui 2011; Tudda 2012; Xia 2006; Yang 2002; Zubok 2009). Two prevailing themes have emerged from these standard accounts. First, changes in Chinese and Soviet positions toward the United States prior to 1969 are not particularly noteworthy since Sino-American and Soviet-American relations basically remained hostile. Second, the Chinese and Soviet pursuit of an alignment with the United States were achievements of the Nixon Doctrine. The focus on the post-1969 turn of events, however, has tended to obscure Soviet and Chinese redefinitions of the primary enemy long before 1969, which had already rendered them unable to focus jointly and primarily on resisting American imperialism. Consequently, against the backdrop of the parallel escalation of the Vietnam War and the Cultural Revolution from 1965-1968, Moscow and Beijing had already begun to reappraise the weight to be assigned to their contradictions with the United States while focusing primarily on countering the threat posed by each other. This indicated, in no small measure, a subtle yet unmistakable reversal of the earlier Cold War relations sealed as a result of the Korean War: Sino-Soviet anti-imperialist partnership and Sino-American confrontation. ${ }^{1}$

By looking into the shifts that occurred in the Chinese and Soviet reappraisal of the United States prior to the Sino-Soviet border clash, the present analysis will address the question of how it had become possible for both Moscow and Beijing to adopt a less ideological view toward Washington prior to 1969. In this connection, the present study will identify the Sino-Soviet split as a process by which Moscow and Beijing ended up reappraising the nature and immediacy of the United States as a consequence of redefining each other as the primary adversary. ${ }^{2}$ This in turn made them willing to address bilateral issues with the United

\footnotetext{
${ }^{1}$ Before the Korean War, American officials were aware of the nationalist character of Chinese communism and its potential for separating eventually from the Soviet Union. However, the Korean War removed any expectation that this could happen in the near future, and prompted the imagery of monolithic communism, popularly used in American justification of expanding containment and increased military spending (Jervis 1980; Gurtov 2010).

${ }^{2}$ There are diverging interpretations of the nature of the Soviet threat from the Chinese point of view. Goldstein argued that the main concern Mao Zedong had regarding the Soviet Union was the ideological threat it was perceived to be posing by way of 'revisionism'. This is said to have been perceived as more dangerous that Soviet "social imperialism" (Goldstein1 994, 246-247). However, it can also be argued that the strategic ramifications of their tension had been apparent since as early as
} 
States in disassociation from the situation in Vietnam and the imperative of committing to a joint anti-imperialist partnership. Section II will first advance a conceptual basis for highlighting the relevancy of the United States in analyzing the breakdown of Sino-Soviet relations. Relying on documents from the Cold War International History Project (CWIHP) established at the Woodrow Wilson Center for International Scholars, the Foreign Relations of the United States (FRUS), as well as other documents containing official Chinese and Soviet positions, Section III will examine the emergence of a Sino-American tacit understanding in contrast to the primary focus placed on anti-Soviet revisionism. Section IV will explore Moscow's progressive willingness to accommodate the United States on the questions of Vietnam and arms control while trying to prevent Sino-American rapprochement. Together, the present study will provide an analytic history of how China and the Soviet Union, despite the denial of their leadership, actually had begun to reverse enemies and friends from 1965-1968.

\section{THE UNITED STATES IN THE CAUSE AND CONSEQUENCE OF THE SINO-SOVIET SPLIT}

Since the Sino-Soviet alliance began as an anti-imperialist partnership predicated on the common designation of the United States as the principal adversary, any inquiry into the rise and fall of this relationship necessarily involves the United States. Broadly, this relationship has been examined in studies dealing with the American wedge strategy as part of its containment policy of undermining Soviet leadership in the international communist movement and trying to keep Moscow and Beijing divided (Chang 1990; Christensen 2005; Gaddis 1987; Khan 2008; Myers 1986; Westad 1996). For the particular purpose of the present study, which is to determine how the fear of allies between Beijing and Moscow from 1965-1968 coincided with the emerging view of the United States as a limited threat, it may be useful to attempt a further conceptual clarification by distinguishing the relevance of the United States in the cause and consequence of the Sino-Soviet split.

The United States had been one of the principal causes of the Sino-Soviet dissension dating back to Nikita Khrushchev's promotion of peaceful coexistence in the mid-1950s (Griffith 1964; Lüthi 2008a; Radchenko 2009; Zagoria 1964). It

1962-1963, when the Soviet Union and the United States found a "community of interest" in jointly thwarting the Chinese nuclear program and China defined it as a "Soviet-American alliance" (Chang 1990). 
was the disagreements about the intentions and capabilities of the United States that irrevocably drove the two allies apart (Westad 1996, 180). In particular, the Sino-Soviet contention over peaceful coexistence following the Soviet launch of the Sputnik in 1957, the Second Taiwan Strait Crisis in 1958, and the KhrushchevEisenhower summit in 1959 amidst Soviet-American discussions toward a moratorium on nuclear testing made the relationship between Mao Zedong and Khrushchev particularly acrimonious (Chang 1988; Gobarev 1999; Jacobson 1996; Shen and Xia 2012). During this time, however, their tensions were basically confined to ideological polemics and involved no critical turn around in their primary enemy designation neither toward each other nor the United States. ${ }^{3}$ Both China and the Soviet Union wished to avoid being the first one to break, and they continued to pay lip service to the imperative of a fraternal ideological alliance. China's radicalism and inward focus during the Great Leap Forward precluded any likelihood of change toward the United States and Khrushchev continued to vacillate between provoking and placating the United States (Zubok 1996). Thus during this time, common ideology basically served to "limit the dispute and prevent it from erupting into an open split" (Zbigniew 1961, 434).

But after the summer of 1962, the Sino-Soviet split began to effect changes in their respective positions toward the United States. This involved different protagonists and issues over time. First, from the second half of 1962, against the backdrop of a significant radicalization of Chinese foreign policy and increasing Soviet-American perception of a community of interests in checking Chinese militancy, the Soviet Union began to seek accommodations with the United States over the issue of nuclear nonproliferation and test ban treaty. Punctuated by the Cuban Missile Crisis, the Soviet action in this direction eventually culminated in the conclusion of the Limited Test Ban Treaty (LTBT) with the United States and the United Kingdom in the July 1963. Denounced as a Soviet-American "alliance" against China by Mao Zedong and his associates, this represented a significant turning point in the long history of the Sino-Soviet conflict because it resulted in an unprecedented level of cooperation between Washington and Moscow over an issue that had antagonized Sino-Soviet relations since the 1950s (Amardeep 2004; Clemens 1968; Burr and Richelson 2000; Mastny 2008; Li 2011; Niu 2006; See 2002). Second, from 1965-1966, China began to redefine the United States as a limited threat (Connolly 2005; Hershberg and Chen 2006; Akira 1968; Lumbers 2004; Lawson 1984; Rogers 1976; Zagoria 1967; Zhai 2001), but in contrast hyperbolized the danger of Soviet revisionism against the backdrop of the

\footnotetext{
${ }^{3}$ For the significance of primary enemy designation in Chinese foreign policy (Van Ness 1970; Khoo 2011).
} 
Vietnam War and the Cultural Revolution. The Soviet Union returned to advancing détente with the United States starting in late 1966. From 1967-1968, both China and the Soviet Union regarded each other as the primary adversary, effectively replacing each other with the United States in this designation. During this time, China continued to be regarded as a cautious revolutionary by the United States. 4 The Soviet Union displayed a stronger willingness to achieve cooperation with the United States on a limited number of issues and became deeply anxious about the possibility of Sino-American rapprochement. Through this process, it became impossible for China and the Soviet Union to be bound by a common ideological foundation built on an agreement of the United States as the primary adversary (Westad 1996). This in turn predisposed them to rapprochement with the United States.

Therefore the Sino-Soviet conflict since the summer of 1962 represented a qualitatively different phase, one that began to involve changes toward the United States on the part of either one of the two protagonists or both; this in turn signaled the incorporation of strategic dimensions in their rivalry, in addition to the ideological contest. The consequences the Sino-Soviet split had on their respective positions toward the United States shows why the Cold War from 1962 can be described as a "multilateral permanent truce" rather than "bipolar brinkmanship" (Zubok and Pleshakov 1996, 7-8). The periodic focus of the present study falls within this period of a "multilateral permanent truce," because both Moscow and Beijing began to redefine their positions toward Washington. Once their conflict began to result in change toward the United States, the Sino-Soviet split reached the point where ideology could no longer hold them together, confirming Walt's earlier argument that "an ideology that directs its adherents to form a single centralized movement is more likely to be divisive than unifying" (Walt 1997, 157). After this point on, both as strategic and/or ideological threats, the antagonism toward each other became the predominant feature of Soviet and Chinese policy. In contrast, their contradictions with the United States receded in the order of priorities. To substantiate the analytic and conceptual validity of highlighting the role of the United States in the consequence of the Sino-Soviet split, the following sections will elaborate on the Chinese and Soviet understatement of anti-American imperialism and eventual move toward a search for a constructive relationship from 1965-1968.

\footnotetext{
${ }^{4}$ Document 312, National Intelligence Estimate: Short Term Outlook in Communist China (23 May 1968), Foreign Relations of the United States (FRUS), 1964-1968, Volume XXX, Soviet Union.
} 


\section{CHINA'S POLICY TOWARD THE UNITED STATES DURING THE SINO-SOVIET SPLIT, 1965-1968}

Following the Tonkin Incident in August 1964, the Vietnam War accelerated the Sino-Soviet rivalry for influence over their Vietnamese comrades and deepened their contention over war strategy. This was compounded by the concurrent intensification of the Cultural Revolution, central to which was the pursuit of antiSoviet revisionism as the primary aim of domestic as well as foreign policy. In this context, the Soviet Union had not only come to "rival the US as a dominant problem for Chinese foreign policy." ${ }^{5}$ From this point on, the Chinese began to concentrate on anti-revisionism to the near exclusion of anti-imperialism (Van Ness 1970). The fear of an offensive from the north (Soviet Union) figured predominantly in China's launch of the Third Line Defense (1964-1971), a relocation of key industrial and research facilities to China's interior (Lewis and Xue 2006). ${ }^{6}$

By contrast, the Chinese leadership progressively downplayed the danger of American imperialism in their official rationale. This stemmed from the imperative of avoiding a Korean War-style Sino-American confrontation.Thus the CCP hierarchy believed that the "struggle with revisionism at home and abroad should take priority over everything else, including the war in Vietnam and struggle against the United States" (Zagoria 1967, 69). By the same token, in the interest of precluding a Sino-American confrontation, the CCP leadership counseled the strategy of guerilla warfare and self-reliance to its Vietnamese counterparts.7 Against this backdrop, each Chinese step in radicalizing anti-Sovietism progressed in tandem with increasing signals toward the United States to keep the war limited to Vietnam.

In the spring of 1965, China and the Soviet Union were in the midst of serious disagreement over united actions in aiding the Democratic Republic of Vietnam

${ }^{5}$ Document 85, "Communist China's Foreign Policy," 5 May 1965, Foreign Relations of the United States (FRUS), 1964-1968, Volume XXX, China.

${ }^{6}$ Luthi (2008) tends to emphasize the weight placed on the American threat rather than the Soviet threat in China's planning and implementation of the Third Line Defense. Throughout the duration of the project, China's perception of which one of the two posed a bigger threat differed by phases. Naughton (1988) argued that the relative weight of the American and Soviet threat was relatively equal until 1966, when following the signing of the Soviet-Mongolian Treaty, the Soviet threat was treated as more serious than the American one. Li Danhui, on the other hand, argued that "as early as June 1964, the Soviet threat was relatively more dangerous than the American one" (Khoo 2011, 174).

${ }^{7}$ Many of the conversations between the CCP and the VWP leadership appear in the collections of documents made available by the Woodrow Wilson International Center for Scholars, such as the Vietnam War digital archive collection (Luthi 2007; Westad and Chen 1988). 
(DRV). Beijing refused to participate in the proposed Moscow Conference from March 1-5, 1965. This was soon followed by the CCP Central Committee's declaration of an organizational break from the CPSU Central Committee, signaled by the publication of the editorial "A Comment on the March Moscow Meeting," on March 23 in Renmin Ribao, accusing the Soviet Union of "reversing enemies and friends" by colluding with the United States and charging the Soviet United Action proposal as a "sham." 8 On May 21, Zhou Enlai even went so far as to elude waging war against the Soviet Union with the following statement: "We will take on both imperialism and revisionism simultaneously. We will fight a nuclear war. ... We will be prepared to fight a war in both directions" (Nui 2006, 325). ${ }^{9}$ In light of these circumstances, even as mayor of Beijing and member of the Chinese Communist Party (CCP) Politburo Peng Zhen outlined American imperialism as the source of principal contradiction in his major speech at the Aliarcham Academy in Indonesia in May 1965, he assigned primary emphasis on the need to struggle against revisionism as the essential element of anti-imperialism. ${ }^{10}$ Based on this formulation, Chinese leaders increasingly argued that the Soviet Union had to be categorically rejected from the broad united front against imperialism. ${ }^{11}$ Such anti-Sovietism culminated in Defense Minister Lin Biao's publication of "Long Live the Victory of the People's War!" on September 3.

In contrast to the organization break between the CCP and the CPSU and the collapse of the Sino-Soviet military alliance at this time, the Chinese public statements started intimating signs of downplaying the threat of American imperialism, mindful of its military weaknesses amidst the expansion of American military intervention (Westad 1998). During this process, what would prevail was a perception that "U.S. intentions, while hardly benign, were not overwhelmingly hostile to China, and could be contained" (Lawson 1984, 133-134). Evidence of such reappraisal of the American threat started appearing as early as January 1965. In his interview with American journalist Edgar Snow published in the New Republic on February 26, Mao Zedong implied the possibility of improved relations with the United States in the long run: "Naturally, I personally regret that forces of history have divided us and separated the American and Chinese peoples from virtually all communications during the past 15 years. Today the gulf

\footnotetext{
8 "A Comment on the March Moscow Meeting," Peking Review 13 (March 26, 1965), 9-10.

${ }^{9}$ Zhou made this remark during a PLA strategy session. According to Niu, it was the "most direct and demonstrative public statement of the Chinese government to date, that if necessary, China contemplated waging war against the Soviet Union.”

10 "Comrade Peng Zhen's Speech at Aliarcham Academy in Indonesia," Peking Review 24 (June $11,1965), 10-11$.

${ }^{11}$ Ibid., 17-18.
} 
seems broader than ever. However, I myself do not believe it will end in war and one of history's major tragedies" (Snow 1965) ${ }^{12}$ Similarly, an article in the New York Times on February 3 carried Mao Zedong's statement that "the U.S. and China would someday be on friendly terms" (New York Times 1965). Revisiting the significance of these remarks, Henry Kissinger described them as "startling," considering these to be evidence of how Mao Zedong "was probably more ready than anyone realized at the time to consider applying the maxim of moving closer to his distant adversary, the United States" (Kissinger 2011, 204). Whether Mao Zedong had already made up his mind as early as this time to eventually pursue a course of rapprochement with the United States, as Kissinger suggested, is debatable. Regardless, such display of Chinese caution toward the United States on the one hand and the refusal to cooperate with the Soviet Union's united action proposal were arousing suspicion in Hanoi about the sincerity of Chinese intentions. For example, GDR Ambassador to the DRV Wolfang Bertold noted Hanoi's growing suspicions of Chinese attitudes as the following:

\begin{abstract}
Among some Vietnamese comrades, doubts about the sincerity of the Chinese leaders and the possibility of aid have occurred. Some start to think about the possibility that the Chinese only use the Vietnamese as a tool of their own, Chinese policy. Such doubts have emerged, among other issues, as the consequence of the events in August and of the related, insufficient aid from the people's republic of China, and also of the general, insufficient aid in the economic sphere. While the Chinese assert that they are ready to support the DRV ("Four Chinese can stand on each square meter of theDRV"), they demand from the Vietnamese to focus on the South. Such comments have caused some Vietnamese to ponder [about the situation] and especially the South is disappointed, so that the NLF is again returning to carrying out individual actions, since it is not in a position to carry out larger military actions without sufficient aid. One can view the [Vietnamese] readiness to negotiations with the US in that context. ${ }^{13}$
\end{abstract}

Mao Zedong's remarks set the tone for subsequent actions and statements by the CCP leadership regarding Chinese policy toward the Vietnam War and the United States. After the launch of Operation Rolling Thunder in March 1965, Chinese leadership began issuing "highly qualified and somewhat ambiguous" statements with added frequency (Rogers 1976, 299). For example, Foreign

\footnotetext{
12 The actual date of the interview was January 9, 1965.

${ }^{13}$ Document 4, "Note No. 2/65 on Conversations with Comrade Shcherbakov about the Developmental Tendencies in the Democratic Republic of Vietnam, on 22 and 28 December 1964, and 6 January 1965," [Source: SAPMO-BArch, DY 30/IV A 2/20/442, 8-10] (Luthi 2007, 373).
} 
Minister Chen Yi's statement on March 28 outlining China's support for North Vietnam and the National Liberation Front (NLF) equivocated on whether it would actually send volunteers. ${ }^{14}$ Chen Yi's statement was followed by Zhou Enlai's attempt on April 2 to inform the United States of China's intent to keep the war limited to Vietnam and avoid a Sino-American confrontation.

First, China will not take the initiative to provoke a war against the United States. ... Second, China means what it says, and China will honor whatever international obligations it has undertaken. ... We are prepared. This is the third point Your Excellency may want to convey to the United States. The United States says that China has not made war preparations, using this to deceive its people. China does not want to fight a war with the United States. ${ }^{15}$

In this connection, Zhou Enlai argued that China would place itself in an advantageous position "if we do not raise the banner of resisting American and aiding Vietnam now and wait until later" during the enlarged politburo meeting on April 12 (Lüthi 2007, 322). The United States, for its part, understood the implications of China's emphasis on self-reliance and Mao Zedong's strategy of "people's war" was intended to deter the United States, as indicated by the National Intelligence Estimate of March $10,1965 \cdot{ }^{16}$ The purge of PLA Chief Luo Ruiqing, who had been

14 “Aiding Vietnam is China's Sacred International Duty (Chen Yi's Reply to Xuan Thuy)," Peking Review 14 (April 2, 1965), 10-11. According to the statement, "China and Viet Nam are closely related like the lips and the teeth and share each other's security and danger. To help the fraternal Vietnamese people resist U.S. aggression is the Chinese people's sacred internationalist duty. We firmly support the March 22 statement of the South Viet Nam National Front for Liberation. The Chinese people will exert every effort to send the heroic south Vietnamese people the necessary material aid, including arms and all other war materiel, and stand ready to dispatch their men to fight shoulder to shoulder with the south Vietnamese people whenever the latter so require."

15 "Zhou Enlai and Pakistani President Ayub Khan," April 2, 1965, The Diplomatic History Research Office of the People's Republic of China Foreign Ministry, comp., Zhou Enlaiwaijiaohuodongdashiji, 1949-1975 (Beijing: World Knowledge Press, 1993), 445, accessed at http://digitalarchive.wilsoncenter.org/document/113057 (March 24, 2013). Muhammad Ayub Khan (1907-1974), a military leader, was president of Pakistan from 1958-1969.

${ }^{16}$ Document 80, "Communist China's Military Establishment," Foreign Relations of the United States (FRUS), 1964-1968, Volume XXX, China, accessed at http://history.state.gov/historicaldocuments/frus1964-68v3o/d8o (March 12, 2013). The document stated, "The Chinese Communists continue to proclaim the military doctrine of Mao Tse-tung which stresses self-reliance, the dominance of men and politics over weaponry, and the concept of a protracted 'people's war.' This doctrine, deemed applicable to 'wars of national liberation,' is also applied to a potential conflict with the US. Communist China is apprehensive regarding the possibility of a US nuclear attack followed by a largescale invasion, but holds that in such a case China could accept nuclear devastation and still overwhelm the invaders in a protracted 'people's war.' The Chinese leaders hope that this prospect will deter the US." 
warning against the probability of American hostilities against China (Harding and Gurtov 1971) illustrated the firm establishment of the basic Maoist position that the "threat from the United States could be contained and that rapprochement with the Soviet Union was unnecessary" (Lawson 1984, 139). A Renmin Ribao article on March 29, 1966 "Old Tune, New Plot," hinted at the long-range possibility of improved relations with the United States: "The Chinese people have always drawn a distinction between U.S. imperialism and the American people. ... We are convinced that someday the Chinese and American peoples will smash the schemesof the U.S. reactionaries, sweep away all obstacles and truly establish close contact so as to bring about at remendous growth of the friendship between our two peoples." 17

On April 10, Premier Zhou Enlai made a four-point statement on China's policy toward the United States in an interview with Pakistan paper Dawn, which basically repeated his message to Pakistani President Khan in $1965 .{ }^{18}$ This statement was particularly significant because "it concentrated directly on SinoAmerican relations and significantly downplayed the importance of the Vietnam War" (Rogers 1976, 310). Chen Yi's statement on September 7, 1966, projecting likelihood of limiting Sino-American conflict and possibly working toward improved relations in the future: "We do not think that the United States would immediately wage a war with us or that the present Sino-American tension will last for a long time. We have no intention to provoke a war with the United States. ... It is wrong to consider that China has no intention of having talks with the United States, and that the two countries will continue negotiations at Warsaw at the ambassadorial level."19 These developments demonstrate how China and the United States progressively moved toward a "tacit understanding" that "neither side desired or encouraged Sino-American confrontation in or over Vietnam" (Yang 2006, 56).

In the same vein, the height of Chinese radicalization during the Cultural Revolution brought no major change to China's cautious approach toward the United States. This basic course remained intact even after the seizure of the foreign ministry by the Red Guards in 1967 (Gurtov 1969). During an interview with a Japanese correspondent in June 1967, Chen Yi stated, "The United States in wondering whether China will participate in the Vietnam War. At present, the Vietnamese people are successfully fighting against the United States forces. The

17 “Old Tune, New Plot," Peking Review 14 (April 1, 1966), 15.

18 "Premier Chou's Four-Point Statement on China's Policy Towards U.S.," Peking Review 20 (May 13, 1966), 5 .

${ }^{19}$ Mainichi, September 71977 (Gottlieb 1977, 44). 
Vietnamese people will be able to defeat the United State without outside aid. The Vietnamese people whom I have met have convinced me of this" (Lawson 1984, 142). During the Warsaw ambassadorial talks on June 14, 1967, Wang only repeated pro forma, standard positions on Vietnam and focused more on Taiwan. ${ }^{20}$ Ambassador John A. Gronouskinoted that "Wang reiterated in completely standard language ChiCom positions on incidents involving ChiCom territorial air and water, alleged U.S. attack, and on Vietnam. No new warnings of ChiCom intervention or involvement in Vietnam. During latter part of meeting in context of referral to possible U.S. extension of war to include territory of DRV, Wang simply said ChiComs had made preparations in event U.S. 'imposes war on Chinese people'." ${ }^{21}$ During the Warsaw ambassadorial talks between the United States and China in January 1968, Gronouski reported to Dean Rusk that the meeting had been "distinguished by a sharp downturn in invective as compared to other meetings in which I have participated, and a complete absence of reference to the Cultural Revolution and the sayings of Chairman Mao."22 According to Gronouski, the Chinese had "reverted to their pre-cultural revolution position that Taiwan is the sole issue poisoning relations between China and the U.S., as against their position over the past couple of years that their conflict with us involved differences encompassing the whole world revolutionary movement." 23 Also, the Chinese side "devoted their entire opening statement to strictly bilateral issues Taiwan and an itemized listing of air intrusions, attacks on ships, etc. and during rebuttal made only perfunctory references to Viet-Nam."24 In February Rusk reported to Johnson that "Peking has been willing, at some political cost, to keep open the Ambassadorial-level contact in Warsaw and clearly sees an advantage in having a communication point with the United States."25

As noted by a U.S. National Intelligence Estimate in May 1968, the Chinese government had "taken steps to reduce the violent and provocative influence of internal affairs on foreign relations. In the main, the Cultural Revolution has not altered the general line of Chinese policy abroad; it still remains revolutionary in tone but cautious and prudent in deeds." ${ }^{26}$ Subsequently, following the Soviet

20 Document 270, “Telegram From the Embassy in Poland to the Department of State," 14 June 1967, Foreign Relations of the United States (FRUS), 1964-1968, Volume XXX, China.

${ }^{21}$ Ibid.

22 Document 296, "Letter From the Ambassador to Poland (Gronouski) to Secretary of State Rusk,” 11 January 1968, Foreign Relations of the United State (FRUS), 1964-1968, Vol. XII, China.

23 Ibid.

24 Ibid.

25 Document 302, "Memorandum From Secretary of State Rusk to President Johnson," 22 February 1968, Foreign Relations of the United States(FRUS), 1964-1968, Volume XXX, China. 
invasion of Czechoslovakia in August 1968, Zhou Enlai stated that the "Soviet Union had degenerated into social-imperialism and social-fascism $\cdots$ that a big nation should have to willfully trampled a small nation underfoot serves as a most profound lesson for those harboring illusions about U.S. imperialism and Soviet revisionism." 27 Soviet military occupation of Czechoslovakia reaffirmed a (greater than) American and immediate threat to China. At the Twelfth Plenum in October 1968, Mao Zedong officially designated Moscow as China's primary adversary following the Soviet invasion of Czechoslovakia. This provided "strong circumstantial evidence suggesting that Mao was closely associated with the "proUS' policy launched by Zhou" (Gottlieb 1977, 25). By 1968, China's contradictions with the United States had receded in importance relative to the primary threat posed by the Soviet Union.

\section{THE SOVIET UNION'S POLICY TOWARD THE UNITED STATES DURING THE SINO-SOVIET SPLIT, 1965-1968}

Faced with a deepening American involvement and intent on reasserting its leadership in the international communist movement, the new Soviet leadership under Leniod Brezhnev and Alexei Kosygin reversed the previous policy of disengagement toward Vietnam and initially toned down the Khruschevian attack on China starting in late 1964. After the ouster of Khrushchev, the Soviet Union sought to assert its leadership in the international communist movement by strengthening its support for the revolutionary struggle in Vietnam and letting the Chinese Communist Party discredit itself rather than engaging in anti-Chinese polemics. These changes signaled a return of the "Stalinist worldview" among the Soviet leadership who assigned a higher priority on rapprochement with China than détente with the United States (Zubok 2007). An important consequence of this policy was the hardening Soviet position toward the United States during the early phase of the Vietnam War. The U.S. Department of State's Policy Planning Council noted in February 1965 that Moscow put relations with the United States in "serious jeopardy" for possible gains in its struggle with China. ${ }^{28}$

${ }^{26}$ Document 312, "National Intelligence Estimate: Short Term Outlook in Communist China (23 May 1968)," Foreign Relations of the United States (FRUS), 1964-1968, Volume XXX, Soviet Union.

27 "Premier Zhou En-lai's Important Speech at Rumania's National Day Reception (23 August 1968)," Peking Review, Supplement to 34 (23 August 1968), III-IV.

28 Document 96, "Memorandum Prepared in the Policy Planning Council (Soviet Policy in Light of the Vietnam Crisis)," 15 February 1965, Foreign Relations of the United States (FRUS), 1964-1968, Volume XIV, Soviet Union. 
However, a confluence of factors starting in the last four months of 1966 led the Soviet Union to reverse the suspension of anti-Chinese polemics and reconsider the reluctance to promote a negotiated settlement of the Vietnam conflict. The key factors that led to the Soviet policy reassessment toward China and the United States were: first, the extreme and violent manifestations of Chinese antiSovietism carried out by the Red Guards during the most radical phase of the Cultural Revolution; second, irreconcilable differences regarding war strategy and tactics in Vietnam; and third, growing signs of flexibility in American policy toward China, including remarks by high-ranking officials calling for containment without isolation and the removal of export restrictions on a large number of nonstrategic items (Zagoria1967, 57). The policy reassessment and reordering of priorities would become increasingly more pronounced after 1967 onward as Moscow increasingly sought to reduce the previous linkage between Vietnam and Soviet-American relations.

The resumption of Soviet anti-Chinese polemics from this point on centered on the charge that the CCP leadership practiced "great power chauvinism" (Radchenkov 2009, 185). The first official attack on Mao Zedong at a plenary session of the central committee of the CPSU from December 12-13, 1966 signaled the launch of this new course of anti-Chinese polemics. Following the siege of the Soviet Embassy in Beijing, the tone of anti-Chinese polemics became even more implacable. The February 16, 1967 analysis of the Cultural Revolution published in Pravda was the most important among the series of attacks that appeared in the Soviet press following the siege of the Soviet embassy in Beijing.

There is no longer any doubt that the desire to divert the Chinese people's attention from the privations and difficulties which they are enduring, and the many mistakes and failures in China's internal and foreign policies, is one of the immediate causes of the present Chinese leadership's anti-Soviet policy and propaganda. It is not accident that they fired the first shots in their political war against the Soviet state and the party shortly after the failure of the 'Great Leap Forward' policy and the people's communes of unhappy memory. ... Soon afterwards purely nationalist and even racialist elements had already become obvious in Chinese propaganda. ... By making the Chinese people believe that they are surrounded by enemies on all sides, the leaders in Peking are trying to organize them on a nationalist basis. They wish to divert the worker's attention from the real problems facing the country and justify the military and bureaucratic dictatorship of Mao Tse-tung and his group (Editorial Staff of Keesing's Contemporary Archives 1969, 101-102). 
The resumption of Soviet anti-Chinese polemics, coupled with the policy of containment that took more concrete shape in the early months of 1967 with the stationing of troops in Mongolia and military buildup along the Sino-Soviet border, indicated the Soviet Union's increasing concerns about China as a strategic threat. ${ }^{29}$ A U.S. National Intelligence Estimate (NIE) at this time noted the hardening public posture of the Soviet Union toward China and its implications for the Sino-Soviet split in the months ahead.

The Sino-Soviet dispute has greatly intensified in recent months. Peking has stepped up the frequency and fury of its attacks on the USSR. Moscow, which for almost two years sought to convey an image of reason and restraint in the dispute, has since August begun to reply forcefully in kind. China accuses the USSR of acting in collusion with the US, and Moscow charges that Peking serves the imperialist cause by refusing to cooperate with the rest of the Communist world. China claims that the Soviet leadership is deliberately transforming the USSR into a bourgeois society, Moscow asserts that current developments and policies in China have "nothing in common with MarxismLeninism." And each side now publicly contends that the other is beyond redemption so long as its present leaders are in control. $3^{30}$

As the Sino-Soviet competition headed toward an open conflict and Soviet anxieties about hostilities with China worsened, Moscow began to reconsider the earlier posture of rigidity toward the United States, particularly over the Vietnam War starting in late 1966. To be sure, a growing Sino-Soviet friction "did not automatically assure a commensurate Soviet effort to improve relations with the West." ${ }^{1}$ However, as "China has become more and more isolated and discredited, the Soviet Union became less sensitive to Chinese accusations and perhaps less responsive to Chinese pressures for militancy."32 But more importantly, as U.S. Ambassador-at-Large Llewellyn Thompson noted, the Soviet Union was "genuinely worried about the chaotic situation inside Communist China and

${ }^{29}$ Radchenko noted, however, that China posed a real but not an immediate threat, since it was not until April 1967 that the Politburo even arranged logistically for sending construction troops to Mongolia to prepare military bases (Radchenko 2009, 189); Document 248, "Soviet Foreign Policy," 28 September 1967, Foreign Relations of the United States (FRUS), 1964-1968, Volume XIV. The document states that the "Soviets have strengthened their armed forces along the Sino-Soviet frontier and in Mongolia and-though probably anticipating only border skirmishing - are probably preparing for more serious contingencies."

${ }^{30}$ Document 223, "The Outlook for Sino-Soviet Relations," Foreign Relations of the United States (FRUS), 1964-1968, 14 October 1966, Volume XIV.

${ }^{31} \mathrm{Ibid}$.

${ }^{32}$ Ibid. 
would like better relations with us not only in the event of unforeseen contingencies but also to deter us from any inclination we might have to get together with Communist China in opposition to the Soviet Union."33

In this connection, several indications of this changing position toward the United States became more notable since late 1966. In particular, the Soviet side began making a less explicit linkage between Soviet-American relations and the Vietnam War. This marked a shift from the previous Soviet position of placing an immediate priority on aiding the DRV at the risk of undermining detente with the United States. During Andrei Gromyko's meeting with Lyndon Johnson on October 10, 1966, Gromyko "declared on behalf of the Soviet Union that it was in our mutual interest to work for better relations. If the United States Government and Mr. Johnson, as President, were willing to take steps to promote international detente to improve relations, they would not find the Soviet Union lacking in response as this was in accord with the wishes of both the Soviet Government and its people." 34 According to the observations by Thompson, "it was striking that Mr. Gromyko avoided all polemics and was most careful not, in any way, to antagonize the President. He made the flat statement that the Soviet Union wished to improve relations which is a considerable change from their recent standard line which is that this could only happen after Viet-Nam was settled."35 Gromyko stressed Soviet readiness to sign a nuclear nonproliferation treaty. ${ }^{6}$ According to American officials, the Gromyko-Johnson talks were the "most direct, honest, objective, and nonideological in several years" (Chang 1990, 275). In a related vein, Brezhnev's speech on November 2 made only a "perfunctory reference to Vietnam in contrast to much sharper sloganeering in the past" (Zagoria 1967, 25).

Conforming to the foregoing analyses, the Soviet Union increased cooperation with the United States on a limited number of issues. On January 18, 1967, the Soviet government issued a statement proclaiming its willingness to engage in dialogue with the United States on the "question of reaching a mutual under-

33 Document 181, "Memorandum From the Ambassador-at-Large (Thompson) to Secretary of State Rusk," 14 October 1966, Foreign Relations of the United States (FRUS), 1964-1968, Volume XIV, Soviet Union.

34 Document 178, "Memorandum of Conversation," 10 October 1966, Foreign Relations of the United States (FRUS), 1964-1968, Volume XIV, Soviet Union.

${ }^{35}$ Ibid.

${ }^{36}$ Document 157, "Memorandum of Conversation," 10 October 1966, Foreign Relations of the United States (FRUS) 1964-1968, Volume XI, Arms Control and Disarmament. Gromyko stated: "The Soviet Union was ready to sign an agreement in two weeks when an agreed text was achieved. The Soviet position was that nuclear weapons must not fall into individual national control of non-nuclear powers or into the collective hands of any grouping that included non-nuclear powers." 
standing with respect to anti-missile systems could be considered simultaneously with a solution of the problem of offensive means of delivering nuclear weapons and in close association with the problem of general and complete disarmament." 37 On January 27, the Outer Space Treaty limiting military uses of spaced was signed by the United States, the Soviet Union and 60 other nations. In 1968, the nuclear nonproliferation treaty (NPT) was signed in August. These agreements did not mean that the Soviet Union was willing to throw its full weight behind cooperation with the United States on a comprehensive program of strategic arms control..$^{3}$ However, even though the Soviet Union and the United States could converge only on a limited form of controls such as the nonproliferation treaty, it nonetheless signaled a departure from the deterioration of SovietAmerican relations during the 1965-1966 period due to the Vietnam War. From 1967, each side became more inclined to engage in consultations on bilateral issues despite difficulties in Vietnam. By January 1968, a paper prepared in the Central Intelligence Agency (CIA) noted that despite the Soviet Union's public posture of hostility toward the United States, Moscow did not let the Vietnam War dictate the state of its bilateral relations with Washington. It read:

\begin{abstract}
Soviet leaders have publicly asserted that no resolution of basic differences with the US is conceivable so long as the US is involved in the war in Vietnam. But they have also indicated (and, during the Middle East crisis, demonstrated) a strong desire to keep the lines open to Washington. And though they have at times insisted that US-Soviet relations must remain frozen for the duration, they have been willing to conclude specific agreements (e.g., on the peaceful uses of outer space) and to negotiate about others (e.g., nuclear proliferation) when they saw larger advantage to Soviet policy. 39
\end{abstract}

In addition to increasing consultations with the United States on the question of arms control and disarmament, the Soviet Union exerted intensified efforts to promote a political settlement to the Vietnam conflict in 1967. In 1967, the Soviet Embassy in Hanoi advised Moscow to inform the North Vietnamese leaders that the "USSR could not afford to pursue a policy of brinkmanship with respect to the

37 Document 174, "Memorandum of Conversation: U.S.-Soviet Discussions on Strategic Nuclear Weapons," Foreign Relations of the United States (FRUS), 1964-1968, Volume XI, Arms Control and Disarmament.

38 Document 248, "Soviet Foreign Policy," 28 September 1967, Foreign Relations of the United States (FRUS), 1964-1968, Volume XIV, Soviet Union.

39 Document 260, “The USSR: Problems, Policies, and Prospects 1967-1968,” 9 January 1968, Foreign Relations of the United States (FRUS), 1964-1968, Volume XIV, Soviet Union. 
United States by getting more deeply involved in the Vietnam conflict, and that therefore the best plan for both the Soviet Union and Vietnam would be if the hostilities drew to a close in 1968" (Gaiduk 1995/96, 254). A May 1967 U.S. Special National Intelligence Estimate projected that "there would also be a good chance that at some juncture the Soviets would exert strong efforts toward a political solution, but they would probably not make Hanoi's acceptance of talks an explicit condition of continued material support."40 That said, the efforts to convince Hanoi to change its intractable position regarding talks with the United States was not very successful in 1967 and its ability to wield influence on Hanoi on negotiating with the United States remained limited at that time. ${ }^{41}$ In particular, since the Soviet Union did not want to open itself up to charges of playing the role of an "appeaser," it was not likely to try to bring any real pressure on Hanoi to modify its terms for a settlement with Washington. ${ }^{42}$ It was not until after the start of peace talks in May 1968 that the Soviet Union played an important de facto intermediary role between the DRV and the United States, and also worked closely with the DRV on negotiation strategies (Khoo 2011). 43

In broadening dialogue with the United States, Moscow's anxieties about SinoAmerican rapprochement weighed heavily. Moscow's interactions with Western leaders in 1967 were marked by harsh anti-Chinese references. In 1967, Soviet diplomats in the West were instructed to solicit opinions of Western politicians regarding the possibilities of Sino-American rapprochement (Radchenko 2009).

$4^{40}$ Document 213, "Soviet Attitudes and Intentions Towards the Vietnam War," Foreign Relations of the United States (FRUS), 1964-1968, Volume XIV, Soviet Union.

${ }^{41}$ As noted by a National Intelligence Estimate in September, "Neither the US nor North Vietnam, the principal actors in the conflict, is very susceptible to Soviet influence; either of them could behave independently in a way which could test the USSR's resolve, strain its resources, and risk its direct involvement." Document 248, "Soviet Foreign Policy," 28 September 1967, Foreign Relations of the United States (FRUS), 1964-1968, Volume XIV, Soviet Union.

${ }^{42}$ Ibid.

43 This, however, did not mean that the Soviet Union was playing a mediating role or putting on pressure on Hanoi to modify its conditions for a settlement. See, Document 281, "Memorandum From the Deputy Director of the Office of National Estimates (Huizenga) to Director of Central Intelligence Helms (Some Signs of Change in Soviet Policy)," 14 July 1968, Foreign Relations of the United States (FRUS), 1964-1968, Volume XIV, Soviet Union. The document reads: "Tactically, Hanoi's move to the negotiating table also frees Moscow to begin at last to talk with the US on Vietnam. That this is happening does not mean that Moscow is now prepared to play a mediating role, however, much less to bring any sort of pressure on Hanoi to settle for less than it wants. Soviet diplomatic activity so far is only parallel and supporting, and appears at every step to be coordinated with the Vietnamese. This will probably continue to be true, for two very substantial reasons. First, the Soviets clearly do not have significant influence on Hanoi's policy. Second, an attempt to put pressure on Hanoi to agree to some 'compromise' solution short of its desires would play into China's hands and probably cost Moscow its entire investment and effort in North Vietnam." 
During Kosygin's visit to London from February 6-13, he urged "Soviet-Western cooperation to contain the Chinese threat and particularly stressed the need to keep any kind of technology of military application out of the hand of the Chinese."44 Likewise, during the Glassboro Summit in June 1967, Kosygin stated, "Viet-Nam had destroyed much that had developed between the United States and the USSR and had given China a chance to raise its head with consequent great danger for the peace of the entire world." 45 By late 1968, after the election of Nixon, Soviet officials made it clear that an improvement in Sino-American relations would be completely incompatible with progress in Soviet-American relations. During a conversation between a second secretary of the Soviet embassy (Boris Davydov) and Governor Averell Harriman's special assistant (Daniel Davidson) in December, for example, Davydov said that "it was no secret that the Soviet Union was greatly concerned over the possibility of a U.S.-Chinese alliance."46

\section{CONCLUSION}

The eventuality of a split between Moscow and Beijing had figured prominently in official Washington since as early as Harry Truman's presidency. He assumed, prophetically, that Mao Zedong would fear the Soviet Union more than the United States (Gaddis 1997); Dwight Eisenhower also wondered whether "the Soviets were not becoming concerned about Communist China as a possible threat to them in the future" (Gaddis 1987, 187). So when Nixon said that he could have his mao tai and vodka, he was operating from the knowledge and anticipation of the Sino-Soviet split that had informed American presidencies from the very early years of the Cold War. This in a way does make the Sino-Soviet split and the parallel detente of 1972 an American achievement, particularly a product of the Nixon Doctrine.With that in mind, what the foregoing analytic history of

\footnotetext{
44 Radchenko 2009, 197; Document 49, "Telegram From the Embassy in the United Kingdom to the Department of State," Foreign Relations of the United States (FRUS), 1964-1968, Volume V, Vietnam. Prime Minister Wilson reported that Kosygin made many harsh references about the Chinese and that the Soviet Union was ready to reconvene the Geneva Conference even without Chinese participation.

45 Document 232, "Memorandum of Conversation," 23 June 1967, Foreign Relations of the United States (FRUS), 1964-1968, Volume XIV, Soviet Union.

${ }^{46}$ Document 332, "Memorandum of Conversation," 21 December 1968, Foreign Relations of the United States (FRUS), 1964-1968, Volume XXX, China. This is a record of conversation between Second Secretary of the Soviet Embassy Boris Davydov and Daniel I. Davidson, Special Assistant to Governor Harriman.
} 
the Sino-Soviet split has tried to show is that certain early conditions for the American achievement of détente predated the Nixon presidency. As a consequence of their effective designation of each other as the main enemy, Moscow and Beijing had begun to reappraise the role of the United States in their threat determination from 1965-1968.

This process in itself, however, did not make parallel détente immediate or inevitable. In both the Soviet Union and China, the desirability of turning to the United States as a potential ally against each other continued to be challenged. The politburo of the CPSU remained ideologically orthodox, with its commission on arms control full of hardliners such as Minister of Defense Andrei Grechko who "believed in Soviet victory in a future world war and felt nothing but contempt for the United States and NATO" (Zubok 2007, 204). It was after the American non-intervention in the Soviet invasion of Czechoslovakia in 1968 and the achievement of strategic parity in subsequent years that Brezhnev felt the conditions to be ripe for pursuing détente (Savranskaya and Taubman 2008). Likewise, there existed strong psychological barrier within the Chinese leadership regarding the feasibility and timing of revising policy towards the United States. The CCP hierarchy, therefore, found it difficult to respond to Johnson's proposals for "containment without isolation" during 1965-1968. It took the end of the most radical phase of the Cultural Revolution and the threat of a major military confrontation with the Soviet Union during the early months of 1969 for the CCP leadership to launch a comprehensive review of its security and foreign policy (Xia 2006, 6).

Although the Soviet Union and China were contemplating changes in policy toward the United States from 1965-1968, it was not ideological tolerance for American imperialism per se that allowed them to initiate a redefinition of their respective relationship with Washington. Rather, this was more an unintended consequence of their unremitting ideological intolerance of each other, coupled with the policy of strategic containment that accelerated after the mid-196os. Therefore, it was the designation of each other as not only the foremost ideological rival but a strategic adversary, rather than fundamental ideological tolerance for the United States in itself, that progressively rendered Soviet and Chinese contradictions with Washington recede in importance. That ideology divided allies more than enemies turned out to be one of the most intriguing ironies of the Cold War, and one that triggered the beginning of its end. 


\section{REFERENCES}

Athwal, Amardeep. 2004. "The United States and the Sino-Soviet Split: The Key Role of Nuclear Superiority.” Journal of Slavic Military Studies 17(2), 271-279.

Akira, Iriye. 1968. U.S. Policy Toward China: Testimony taken from the Senate Foreign Relations Committee Hearing-1966. Boston, MA: Little, Brown and Company.

Brzezinski, Zbigniew. 1967. The Soviet Bloc: Unity and Conflict. Cambridge, MA: Harvard University Press. . 1961. "The Challenge of Change in the Soviet Bloc." Foreign Affairs 39(3), 430-434.

Bundy, William. 1998. A Tangled Web: The Making of Foreign Policy in the Nixon Presidency. New York, NY: Hill and Wang.

Burr, William. 2001. "Sino-American Relations, 1969: The Sino-Soviet Border War and Steps TowardsRapprochement." Cold War History 1(3), 73-112. Burr, William and Jeffrey Richelson. 2000. "Whether to 'Strangle the Baby in the Cradle': The United States and the Chinese Nuclear Program." International Security 25(3), 54-99.

Chang, Gordon. 1988. “JFK, China, and the Bomb.” The Journal of American History 74(4), 1287-1310.

. 1990. Friends and Enemies: The United States, China, and the Soviet Union, 1948-1972. Stanford, CA:Stanford University Press.

Chen, Jian. 2001. Mao's China and the Cold War. Chapel Hill, NC: University of North Carolina Press.

Chen, Jian and David Wilson. 1998. "New Evidence on Sino-American Opening: 'All Under the Heaven is Great Chaos': Beijing, the Sino-Soviet Border Clashes, and the Turn Toward Sino-American Rapprochement, 19681969." Cold War International History Project (CWIHP) Bulletin 11, 155175 .

Clemens, Walter. 1968. The Arms Race and Sino-Soviet Relations. Stanford, CA: The Hoover Institution.

Connolly, Chris. 2005. "The American Factor: Sino-American Rapprochement and Chinese Attitudes to the Vietnam War, 1968-72." Cold War History 5(4), 501-527.

Editorial Staff of Keesing's Contemporary Archives. 1969. The Sino-Soviet Split. New York: Charles Scribner's Sons, 101-102.

Foreign Relations of the United States (FRUS). Kennedy Administration Collection.Various years. Accessed at http://history.state.gov/historical- 
documents/kennedy.

. Johnson Administration Collection.Various years. Accessed at http://history.state.gov/historicaldocuments/johnson.

Gaddis, John L. 1987. Long Peace: Inquiries into the History of the Cold War. Oxford: Oxford University Press.

1997. We Now Know: Rethinking Cold War History. Oxford: Oxford University Press.

Gaiduk, Ilya. 1995/96. "The Vietnam War and Soviet-American Relations, 19641973: New Russian Evidence." Cold War International History Project (CWIHP) Bulletin 6/7, 232, 250-258.

. 1996. Confronting Vietnam: Soviet Policy toward the Indochina Conflict 1954-1963. Chicago, IL: Ivan R. Dee.

Garver, John. 1982. China's Decision for Rapprochement with the United States, 1969-1971. Boulder, CO: Westview Press.

Goldstein, Steven. 1996. "Nationalism and Internationalism: Sino-Soviet Relations.” In Thomas W. Robinson and David Shambaugh eds., Chinese Foreign Policy: Theory and Practice. Oxford: Oxford University Press, 224-265.

Gobarev, Victor. 1999. "Soviet Policy Toward China: Developing Nuclear Weapons, 1949-1969.” Journal of Slavic Military Studies 12(4), 1-53.

Gurtov, Melvin. 1969. The Foreign Ministry and Foreign Affairs in China's Cultural Revolution. Santa Monica, CA:Rand Corporation. . 2010. "From Korea to Vietnam: The Origins and Mindset of American Intervention.” The Asia Pacific Journal. Accessed at http://japanfocus.org/ -Mel-Gurtov/3428 (April 23, 2013).

Gottlieb, Thomas. 1977. Chinese Factionalism and the Origins of the Strategic Triangle. Santa Monica, CA: Rand Corporation.

Harding, Harry. 1992. A Fragile Relationship: The United States and China Since 1972. Washington, D.C.: Brookings Institution.

Harding, Harry and Melvin Gurtov. 1971. The Purge of Lo Jui Ching: The Politics of Chinese Strategic Planning. Santa Monica, CA: Rand Corporation, vi.

Haslam, Jonathan. 2011. Russia's Cold War. New Haven, CN: Yale University Press. Hershberg, James G. and Chen Jian. 2006. "Informing the Enemy: SinoAmerican 'Signaling' and the Vietnam War, 1965.” In Priscilla Roberts ed., Behind the Bamboo Curtain: China, Vietnam, and the World Beyond Asia. Stanford, CA: Stanford University Press, 193-258.

Humes, James and Jarvis Ryals. 2009. Only Nixon: His Trip to China Revisited and Restudied. Lanhan, MD: University Pressof America.

Jacobson, Harold. 1996. Diplomats, Scientists and Politicians: The United States 
and the Nuclear Test Ban Negotiations. Ann Arbor, MI: University of Michigan Press.

Jervis, Robert. 1980. "Impact of the Korean War on the Cold War." Journal of Conflict Resolution 24(4), 563-592.

Khan, Sulmaan. 2008. "The Aesthetic of Analysis: National Intelligence Estimate and Other American Appraisals of the Cold War Triangular Relationship." Diplomatic History 32(5), 869-897.

Khoo, Nicholas. 2011. Collateral Damage: Sino-Soviet Rivalry and the Termination of the Sino-Vietnamese Alliance, 1964-1979. New York: Columbia University Press.

Kissinger, Henry. 1979. The White House Years: Years of Upheaval. New York: Little, Brown and Company. . 2011. On China. New York: Penguin Books.

Kirby, William, Robert Ross and Li Gong. 2005. Normalization of U.S.-China Relations: An International History. Cambridge, MA: Harvard University Press. Lawson, Eugene. 1984. The Sino-Vietnamese Conflict. New York: Praeger.

Lewis, John Wilson and XueLitai. 1988. China Builds the Bomb. Stanford, CA: Stanford University Press.

. 2006. Imagined Enemies: China Prepares for Uncertain War. Stanford, CA: Stanford University Press.

Li, Minjiang. 2011. "Ideological Dilemma: Mao's China and the Sino-Soviet Split, 1962-63." Cold War History 11(3), 387-419.

Lin, Biao. 1965. "Long Live the Victory of the People's War!" Peking Review 36, 9-36.

Lumbers, Michael. 2004. “The Irony of Vietnam: The Johnson Administration's Tentative Bridge Building to China, 1965-1966." Journal of Cold War Studies 6(3), 69-111.

Lüthi, Lorenz. 2007. "Twenty-four Soviet Bloc Documents on Vietnam and the Sino-Soviet Split, 1964-1966." Cold War International History Project (CWIHP) Bulletin 18, 369-400. . 2008a. The Sino-Soviet Split: Cold War in the Communist World. Princeton, NJ: Princeton University Press. . 2008b. "The Vietnam War and China's Third Line Defense Planning before the Cultural Revolution, 1964-1966." Journal of Cold War Studies 10(1), 26-51.

Macmillan, Margaret. 2007. Nixon and Mao: The Week that Changed the World. New York: Random House.

Mastny, Vojtech. 2008. “The 1963 Nuclear Test Ban Treaty: A Missed Opportunity for Détente?" Journal of Cold War Studies 10(1), 3-25. 
Myers, David Allan. 1986. Cracking the Monolith: The United States Policy against the Sino-Soviet Alliance, 1949-1955. Baton Rouge, LA: Louisiana State University Press.

Naughton, Barry. 1988. "The Third Front: Defense Industrialization in the Chinese Interior." China Quarterly 115, 351-386.

New York Times. 1965. "Mao said to assert that Viet Cong will Win" (February 15). Niu, Jun. 2006. "The Background to the Shift in Chinese Policy toward the United States in the Late 1960s." In Priscilla Roberts ed., Behind the Bamboo Curtain: China, Vietnam, and the World Beyond Asia. Stanford, CA: Stanford University Press, 319-348.

Peking Review. 1965-1968. (various issues).

Radchenko, Sergey. 2009. Two Suns in the Heavens: The Sino-Soviet Struggle for Supremacy, 1962-1967. Washington, D.C.: Woodrow Wilson Center Press.

Robinson, Thomas and David Shambaugh. 1996. Chinese Foreign Policy: Theory and Practice. Oxford: Oxford University Press.

Rogers, Frank E. 1976. "Sino-American Relations and the Vietnam War." China Quarterly 66, 293-314.

Ross, Robert. 1995. Negotiating Cooperation: The United States and China, 1969-1989. Stanford, CA: Stanford University Press.

Savranskaya, Svetlana and William Taubman. 2008. "Soviet Foreign Policy, 1962-1975." In Odd Arne Westad and Melvyn Leffler eds., Cambridge History of the Cold War II. Cambridge: Cambridge University Press, 140-155.

See, Jennifer. 2002. "An Uneasy Truce: John F. Kennedy and the Soviet-American Détente, 1963." Cold War History 2(2), 161-194.

Shen, Zhihua and Danhui Li. 2011. After Leaning to One Side: China and Its Allies in the Cold War. Washington, D.C.: Woodrow Wilson Center Press.

Snow, Edgar. 1965. "Interview with Mao." New Republic (February 26). Accessed at www.newrepublic.com/article/world/89494/interview-mao-tse-tungcommunist-china (January 12, 2013).

Tudda, Chris. 2012. A Cold War Turning Point: Nixon and China, 1969-1972. Baton Rouge, LA: Louisiana State University Press.

Van Ness, Peter. 1970. Revolution and Chinese Foreign Policy: Peking's Support for Wars of National Liberation. Berkeley, CA: University of California Press.

Walt, Stephen. 1997. "Why Alliances Endure or Collapse." Survival 39(1), 156-179. Westad, Odd Arne. 1996. "The Sino-Soviet Alliance and the United States." In Odd Arne Westad ed., Brothers in Arms: The Rise and Fall of the SinoSoviet Alliance, 1945-1963. Washington, D.C.: Woodrow Wilson Center Press, 165-188.

1998. "History, Memory, and the Languages of Alliance-Making." In Odd 
Arne Westad et al., eds., 77 Conversations Between Chinese and Foreign Leaders on the Wars in Indochina, 1964-1977, Cold War International History Project Working Paper 22. Washington, D.C.: Woodrow Wilson Center for International Scholars, 8-19.

Wilson, John Lewis and Xue Litai. 2006. Imagined Enemies: China Prepares for Uncertain War. Stanford, CA: Stanford University Press.

Woodrow Wilson Center for International Scholars Digital Archive.Chinese Foreign Policy. Accessed at http://digitalarchive.wilsoncenter.org/collection/20/chinese-foreign-policy.

. Sino-Soviet Relations. Accessed at http://digitalarchive.wilsoncenter.org/ collection/72/sino-soviet-relations/8.

. Sino-Soviet Split. Accessed at http://digitalarchive.wilsoncenter.org/collection/ 73/sino-soviet-split.

. Soviet Foreign Policy. Accessed at http://digitalarchive.wilsoncenter.org/ collection/75/soviet-foreign-policy.

. United States-Soviet Relations. Accessed at http://digitalarchive.wilsoncenter.org/collection/84/united-states-soviet-relations.

. Vietnam War. Accessed at http://digitalarchive.wilsoncenter.org/collection/87/vietnam-war.

Xia, Yafeng. 2006. "China's Elite Politics and Sino-American Rapprochement, January 1969 February 1972." Journal of Cold War Studies 8(4), 3-28.

Yahuda, Michael. 1972. "Kreminology and the Chinese Strategic Debate, 19651968.” China Quarterly 49, 32-75.

Yang, Kuisong. 2002. "Changes in Mao Zedong's Attitude toward the Indochina War, 1949-1974." Cold War International History Project Working Paper 34. Washington, D.C.: Woodrow Wilson Center for International Scholars. 2006. "Mao Zedong and the Indochina Wars." In Priscilla Roberts, ed., Behind the Bamboo Curtain: China, Vietnam, and the World Beyond Asia. Stanford, CA: Stanford University Press, 55-96.

Zagoria, Donald. 1964. The Sino-Soviet Conflict, 1956-1961. Princeton, NJ: Princeton University Press. . 1967. Vietnam Triangle: Moscow, Peking, Hanoi. New York: Pegasus.

Zhai, Qiang. 2001. China and the Vietnam Wars, 1950-1975. Chapel Hill, NC: University of North Carolina Press.

Zubok, Vladislav and Constantine Pleshakov.1996. Inside the Kremlin's Cold War: From Stalin to Khrushchev. Cambridge, MA: Harvard University Press. Zubok, Vladislav. 2007. A Failed Empire: The Soviet Union in the Cold War from Stalin to Gorbachev. Chapel Hill, NC:University of North Carolina Press.

[Received March 31, 2014; Revised May 12, 2014; Accepted J une 5, 2014] 